\title{
Association among Domestic Activities, Culture and Role of Educated Women and Cable Television in War Affected Area Swat
}

\author{
Sajjad Ali ${ }^{*}$, Muhammad Shahzad ${ }^{1}$, Zahid Khan ${ }^{2}$ and Junaid Nazir ${ }^{1}$ \\ ${ }^{1}$ Department of Media Studies, The Islamia University of Bahawalpur, Pakistan \\ ${ }^{2}$ Department of Statistics, University of Malakand at Chakdara, Dir (Lower) Khyber Pathtunkhwa, Pakistan
}

\begin{abstract}
This study was conducted to assess the effects of watching cable television on some characteristics of women. Population of the study was the educated women between ages 18-30 of District Swat, Khyber Pathtunkhwa was selected. Purposive sampling method was used to select sample from the population. Total Eighty-nine respondents were selected from the population as a unit of analysis to investigate the effects. A structured questionnaire was used to collect the information from the respondents. Descriptive statistics was used to present the data through tables. The result was generalized to the population through chi-square test of association. The result analyzed, that the variables; domestic activities, culture and role of women were significantly associated to the exposure of cable television. Government and private companies have the responsibilities to promote the culture, domestic activities and role of women of Pashtun society by introducing special channel on cable television or frame programs on the existing channels.
\end{abstract}

Keywords: War affected; Swat; Educated women

\section{Introduction}

Cable television has significantly affected at least each and every aspect of life of human being. As teenagers and old person almost all are watching foreign channel on cable television. Men and women are fond of watching the television for different purposes through out the world.

Media is playing key role in promoting culture, affecting domestic activities and changing women's role. Most of the people claim that media is significant part of their lives. Media cover the entire region in the world, making it a progressive industry [1]. Cable television plays an important role in linking media and society. This linkage is limited to television viewers. The effects of cable television on the people are controversial between researchers.

Some researchers claim positive and others show negative effects. Jensen and Oster [2] is in the favor of cable television He finds that status of woman improves due to exposing to it. While Zia [3] finds out that cable television negatively affect the social life of women. Her research study is based on Lahore, Pakistan. She finds that; disturbance in domestic activities, wife and husband interaction, social interaction, appearance and style, cultural practices, mother and children interaction, personal and domestic expenditure and social role of Pakistani women have significant effect on exposure. The researcher uses chi-square test to analyze the effects of independent variable, exposure, on all dependent variables separately.

Complete way of life of people is called culture. It consist the shared attitude, goals, value, their customs, language, art, literature, philosophy, religion etc. in other words culture is the way shared by the members of a society, their ideas, beliefs, language, values, knowledge and custom etc. culture can be visible in the behavior of individuals. It exists in the habit of the members of a society. Every society has its own discrete identity by different and separate culture from others.

Hollywood presents Western culture which differs from the Eastern culture. Therefore, the culture of the Eastern world can be affected [4].

Approximately half of the population of Pakistan is women. Their role should be focused as they are major segment of the society. They have importance in the social, economic, agricultural, bureaucratic and educational aspects of a society. In all fields of life, contribution of women is not less than men. Due to this importance every one should acknowledge the significance of the role of women in Pakistan [5]. Thus by watching cable television the role of women is significantly affected.

Pakistan is a developing country and came into existence in 1947. Khyber Pakhtunkhwa is one of the populous provinces of the country. District swat is one of the beautiful places of the province as well as the world. It is famous as the Switzerland of Pakistan. Although it is affected by war against terrorism but still the ratio of education is quite high. Both women and men have high ratios of education. Women of this district are spending most of time in their homes.

Majority of them are house wives and others are students or on job. Most of them are watching different channels on cable television. In this study, researchers investigate the effect of watching cable television on the domestic activities, Pashtun culture and role of educated women in district Swat.

\section{Methodology}

The population of this study has the educated women of district swat between ages 18-30. Total number of Eighty nine samples was selected from the whole district. Purposive sampling method was used to select the respondents. Information was collected through structure questionnaire. 'Cultivation theory used as theoretical framework for the study. It is presented by George Gerbner stated that heavy viewer

*Corresponding author: Sajjad Ali, Department of Media Studies, The Islamia University of Bahawalpur, Pakistan, E-mail: sajjadjmc.uop@gmail.com

Received January 16, 2013; Accepted January 21, 2013; Published January 28, 2013

Citation: Ali S, Shahzad M, Khan Z, Nazir J (2013) Association among Domestic Activities, Culture and Role of Educated Women and Cable Television in Wa Affected Area Swat. J Mass Communicat Journalism 3:146. doi:10.4172/2165 7912.1000146

Copyright: (c) 2013 Ali S, et al. This is an open-access article distributed under the terms of the Creative Commons Attribution License, which permits unrestricted use, distribution, and reproduction in any medium, provided the original author and source are credited. 
of television is affected more than the moderate and light viewer. $\mathrm{He}$ argues that television is central cultural arm of the society. He also claims that television is a key figure of a family which tell all the stories most of the time. Cultivation theory is based on comparative study of heavy and light viewers of the television. Due to the different answers have given by the viewers of television, Gerbner has analyzed that heavy viewers are affected more than the moderate and light viewers by the television [6].

To present the data, frequency distribution method was used. For testing significance of association among exposure, domestic activities, culture and role of women in population, Chi-Square method of both Pearson and likelihood ratio have used.

\section{Objective of the study}

1. To determine the effect of watching cable television on the domestic activities of women of swat

2. To assess the effect of watching cable television on the culture of Pashtoon society

3. To assess the effect of viewing cable television on the role of women

\section{Research hypothesis}

1) The greater the exposure to cable television the greater will be effect on the culture of the area

2) The greater the exposure to cable television the greater will be effect on the domestic activities

3) The greater the exposure to cable television the greater will be effect on the women role

\section{Result and Discussion}

In this study the researcher focused on the some characteristics of women of district Swat, watching cable television. The characteristics are domestic activities, culture and role of women.

\section{Domestic activities and exposure}

The term domestic activities have very vast in its meaning. It included serving time, newspapers and magazines reading, cooking, listening music, outing, watching movies, shopping, prayers and reading of books.

Table 1 show that 32 respondents agreed with medium effect on domestic activities due to exposure and 57 respondents agreed with highly effect of viewing cable television on the domestic activities.

Table 2 indicates that domestic activates have significantly disturbed due to exposure. Women have fond of Western type cooking. Their serving time has been disturbed significantly. They gave much time to cable television and their serving time is decreased.

Habit of reading magazines and newspapers is affected severely due to cable television. Most of the times they have watch movies instead of their cultural music. They do not go outside to watch movies. They watch it in their homes through cable television.

\begin{tabular}{|l|l|l|}
\hline Level of agreement & Frequency & Percent \\
\hline Medium agreed & 32 & 36 \\
\hline Highly agreed & 57 & 64 \\
\hline Total & 89 & 100 \\
\hline
\end{tabular}

Table 1: Frequency distribution of respondent of domestic activities.

\begin{tabular}{|l|l|l|l|}
\hline & Value & Df & Sign. \\
\hline Pearson Chi-Square & 6.11 & 2 & .047 \\
\hline Likelihood ratio & 6.99 & 2 & .030 \\
\hline Sample size & 89 & & \\
\hline
\end{tabular}

Df: Degrees of Freedom; Sign: Significant that there is association between two variables

Table 2: Chi-Square test for association: Exposure and effect on domestic activities.

\begin{tabular}{|l|l|l|}
\hline Level of agreement & Frequency & Percent \\
\hline low & 2 & 2 \\
\hline medium & 32 & 36 \\
\hline high & 55 & 62 \\
\hline total & 89 & 100 \\
\hline
\end{tabular}

Table 3: Frequency distribution of respondent of culture activities.

\begin{tabular}{|l|l|l|l|}
\hline & Value & df & Sign. \\
\hline Pearson Chi-Square & 4.20 & 2 & .122 \\
\hline Likelihood ratio & 4.92 & 2 & .085 \\
\hline Sample size & 89 & & \\
\hline
\end{tabular}

Df: Degrees of Freedom; Sign: Significant that there is association between two variables

Table 4: Chi-Square test for association between exposure and culture activates.

Their shopping habits have changed due to watching of cable television. They have been buying Indian and Western type of dress and Jewelers etc. They have not like Pakhtun dress. Watching foreign movies have a hobby of the educated women of Swat; therefore, they do not perform prayers five times a day do not read books including religious ones.

\section{Culture activities}

The second variable, tested for association with exposure have culture activities of educated women of District Swat.

Two respondents agreed with the low effect on culture due to watching of cable television (Table 3). Thirty two respondents in the sample agreed with medium effect and fifty five agreed with high effect on culture by exposure of cable television.

Table 4 indicated that the association is insignificant by Pearson chi Square test and significant by likelihood ratio test. We can conclude that there has strong association between exposure of cable television and culture activities. Where culture activities, have consisted of food habit, dress, and use of language and religious activities. Thus, by watching cable television dresses, food habits, language and religious activities of the women have been changed.

\section{The role of women}

It has quit a large meaning, women have been claiming; equal career as male counterpart, sharing of family responsibility by men and women, equal rights of men and women, equally sharing family responsibility by husband and wife (Table 5).

In our sample size twenty eight respondents are medium agreed with changing the role of educated women of District Swat by watching cable television. While the remaining sixty one have agreed with high affect on the role of women by viewing cable television. No respondent agreed with low effect.

Concerning analysis, the chi square test of association in table No. 6 indicated that there has significant association between exposure of cable television and role of educated women of District Swat. This 


\begin{tabular}{|l|l|l|}
\hline Level of agreement & Frequency & Percent \\
\hline Medium & 28 & 31 \\
\hline High & 61 & 69 \\
\hline total & 89 & 100 \\
\hline
\end{tabular}

Table 5: Frequency distribution of respondent on role of women.

\begin{tabular}{|l|l|l|l|}
\hline & Value & df & Sign. \\
\hline Pearson Chi-Square & 6.186 & 2 & .045 \\
\hline TLikelihood ratio & 6.300 & 2 & .043 \\
\hline Sample size & 89 & & \\
\hline
\end{tabular}

Df: Degrees of Freedom; Sign: Significant that there is association between two variables

Table 6: Chi-Square test for association between exposure and role of women.

variable have significant at $5 \%$ level of significant. The significant of the test employ that the result of association can be applied on the population i.e. the whole number of educated women of District swat (Table 6).

\section{Conclusion and Policy Recommendation}

Majority of women in district Swat have access to cable television. They have been spending much time to view different types of programs, movies, dramas and songs etc. Majority of the women have agreed to the fact that due the habit of watching cable television, their life style changed rapidly. Their cooking, reading books, religious activities, cultural norms, domestic activities have significantly affected.

The study supports the assumptions of the Cultivation theory that heavy viewers are affected more than moderate and light because they consistently expose to the television. He argues that the television has small but long term effect on the viewers. He also claims that television has significance influence on belief, attitude and judgment of the heavy viewers compared to the light viewers.

There were some positive effects of viewing cable television. The women became able to know about their true status in the society. They were aware of their responsibilities in home and out side. They understand the way of claiming their rights through positives ways. They know national and international organization working for women rights.

Culture of the nation has assets for its people. But unfortunately, it was affected by viewing of cable television. Majority of women of District Swat agreed that their culture was affected negatively. Majority of them did not like the Pashtun culture. They were following Western and Indian culture. In Pashtun society some positive cultural norms like hospitality, braveness and loyalty, only were affected. While others negative cultural norms like exploitation of women by men etc decreased by awareness of women through cable television.

In the past, Pashtun society considered women only for domestic activities. Now this concept is decreasing. Women know that they are not for domestic activities but also for other positive activities. Due to watching cable television, the domestic activities of women were also affected. They were cooking Western and Indian types of dishes. It is positive step to cook not only local dishes but also international recognized dishes. But viewing cable television negatively affected the religious actives like prayers, reading of religious books etc.
The negative effect of watching cable television can remove through some steps:

1. Quality channels might be opened for improving the positive point of culture of Pashtun society like hospitality, loyalty and braveness etc.

2. Religious scholars have the responsibility to spread awareness among women about the importance of religious activities through books, magazine, newspaper, television etc.

3. Government should ban the channel on cable television, responsible for negative propaganda against Pashtun culture.

4. Private television owners should introduce programs for promoting Pashtun culture.

5. The women of study area should also have responsibility to follow positive points of Pashtun culture.

\section{References}

1. Wange HL (2009) The impact of foreign programs on Taiwanese youth and the significant role of media education. Asian culture and history 1: 161-169.

2. Jensen R, Oster E (2009) The Power of TV: Cable Television and Women's Status in India. The Quarterly Journal of Economics 124: 1057-1094.

3. Zia A (2007) Effects of cable television on women in Pakistan: a comparative study of heavy and light viewers in Lahore. Unpublished doctoral dissertation, University, Lahore, Pakistan.

4. Khan AM, Arif I (2009) Media imperialism and its effects on culture of Pakistan, a case study of youth of Multan. Global media journal 2: 1.

5. Sani (2009) Role of women in Pakistani society.

6. McQuail D, Windahl S (1993) Communication models for the study of mass Communication. London: Longman. 